\title{
Mucous Patch on the Tongue as Isolated Manifestation of the Secondary Stage of Syphilis - Case Report
}

\author{
Milan Bjekić ${ }^{1}$, Sandra Šipetić ${ }^{2}$ \\ 'City Institute for Skin and Venereal Diseases, Belgrade, Serbia; \\ ${ }^{2}$ Institute of Epidemiology, School of Medicine, University of Belgrade, Belgrade, Serbia
}

\begin{abstract}
SUMMARY
Introduction Syphilis is sexually transmitted infection caused by the anaerobic spirochete Treponema pallidum. Oral lesions are present and described in all stages of the disease. These lesions as well as blood and saliva of infected persons are highly contagious in early syphilis. The aim of this case report was to point out to the possibility of the secondary syphilis in differential diagnosis of oral diseases.

Case Report A 38-year-old asymptomatic man showed up at the clinic with suspicious of syphilis infection. Clinical presentation of the disease was a mucous patch on the tongue, however no other mucous membrane or cutaneous lesions were detected. No lymph nodes were enlarged. The serologic tests on syphilis were positive. After conducting systemic antibiotic therapy with benzathine penicillin the tongue lesion disappeared.

Conclusion Depending on the clinical picture, the possibility of syphilis should not be overlooked in the differential diagnosis of oral lesions.
\end{abstract}

Keywords: syphilis; oral lesions; mucous patch

\section{INTRODUCTION}

Syphilis is bacterial sexually transmitted infection caused by the spirochete Treponema pallidum. If not treated it shows the following stages: primary, secondary, latent and tertiary. Except for the latent stage, lesions in oral cavity are described in all stages [1]. During the secondary stage, oral lesions, saliva and blood of infected person are very contagious.

Unprotected oral sexual intercourse is very common way of transmission of this disease, especially in men who have homosexual intercourse [2]. The aim of the study was to present a clinical case of oral lesions as manifestation of the secondary stage of syphilis and the importance to take into consideration this "great imitator" in the differential diagnosis of oral diseases.

\section{CASE REPORT}

A 38-year-old bisexual male appeared in August 2010 at the clinic of the City Institute for Skin and Venereal Diseases in Belgrade because of suspicious of syphilis infection. Data from medical history revealed that 3 months ago he had repeated sexual intercourse with a married couple who were treated from this disease. He practiced unprotected oral and receptive anal intercourse.

The patient was asymptomatic. He denied the presence of ulcers in anogenital region and oral cavity. Clinical examination showed no changes of the skin or in the anogenital region, whereas lymph nodes were not enlarged.
By oral cavity inspection an asymptomatic, well circumscribed, slightly elevated mucosal plaques about $1 \mathrm{~cm}$ in diameter (Figure 1) was observed on the tongue. Serological tests for syphilis VDRL (Venereal Disease Research Laboratory) and TPHA (Treponema pallidum Haemagglutination Assay) were reactive. VDRL test had the titer of 1:32.

The patient was treated with a single dose of 2.4 million IU of benzathine penicillin G. The tongue lesion completely subsided two weeks after the treatment. Three months check up showed VDRL test unreactive.

\section{DISCUSSION}

Syphilis is a "great imitator" but oral lesions may be the first signs of the disease. After orogenital or oroanal sexual intercourse at the site of entry of T. pallidum in the mouth, usually after three weeks (incubation of 10 to 90 days), the primary chancre - ulcus durum appears. It is clearly circumscribed solitary painless ulcer with a clean, indurated base and raised edges, usually localized on the lips or a tongue, accompanied by a cervical lymphadenopathy. A rare appearance of a chancre on the tonsils and the pharynx has been described [3].

The primary stage of infection has not been registered in our patient. Medical history data indicated that the primary lesion might be present in the mouth or rectum. At these locations a chancre is often overlooked. If the disease is not diagnosed and properly treated after 4 to 10 weeks bacteria disseminate hematogenously and the secondary stage of syphilis occurs. 


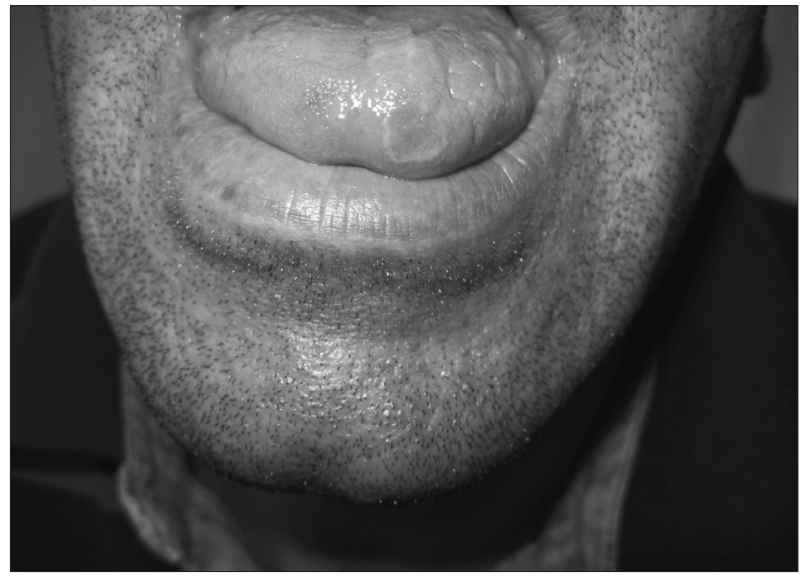

Figure 1. Mucous patch on the tongue

Slika 1. Mukozni plak na jeziku

Oral manifestations of the secondary stage of the disease in the form macular and papular lesions, mucous plaques, and rarely nodular events are present in at least $30 \%$ of patients [1]. Macular lesions usually occur on the hard palate as red circular, flat to slightly elevated maculas. Papular lesions on the buccal mucosa are presented as erythematous firm papules with gray center that can be ulcerated. A special form of papular lesions are very infectious condylomata lata, a light pink - greyish papules, 0.5 to $2 \mathrm{~cm}$ in diameter, with flattened and moist eroded surface, covered with whitish discharge, and located at the corners of mouth. Nodular lesions may occur in the area of vermilion in the form of nodule that clinically resembles keratoakantoma.

Mucous plaques are oval or circular plaques with a thin mucosa on which shallow erosions about $1 \mathrm{~cm}$ in diameter, covered with a gray mucous exudates with erythematous edge can appear on the buccal mucosa and tongue, sometimes on the pharynx, gums and tonsils. Sometimes these changes become fluent and make serpentine like lesions, so-called "snail track" ulcers.

Mucous plaque on the tongue was the only manifestation of secondary syphilis in our patient. The literature has described only a few isolated cases where oral lesions were the only manifestations of this stage of the disease [4-7]. Since these changes are very infectious, timely diagnosis and early treatment is very important. A single dose of 2.4 million IU benzathine penicillin $\mathrm{G}$ is the treatment of choice for secondary syphilis.

The lesions that characterize the tertiary stage of syphilis in the oral cavity are syphilis gumma and syphilis leukoplakia [1]. Gummas, destructive granulomas usually occur on the hard palate and tongue as painless one or more nodes that can ulcerate, cause bone destruction, perforation of the palate and the emergence of oronasal fistula. Syphilis leukoplakia appears as a whitish homogeneous area which covers a larger surface of the dorsal tongue. This glossitis can show malignant alteration.

Polymorphism of clinical findings in oral cavity in syphilis, their high infectivity and the fact that syphilis facilitates the transmission of HIV infection indicate that this disease should not be overlooked in the differential diagnosis of oral lesions such as candidiasis, oral hairy leukoplakia, lichen planus and oral squamous cell carcinoma [7-10].

Early detection of characteristic oral lesions facilitates the diagnosis and enables prompt treatment of syphilis. Therefore, careful inspection of oral cavity is very important in all patients with the suspicion of this disease. Also, they should be continuously educated about the importance of regular use of protective means during any type of sexual intercourse.

\section{ACKNOWLEDGEMENT}

This work is part of the project Number 175042 (20112014) fully funded by the Ministry of Education and Science Republic of Serbia.

\section{REFERENCES}

1. Leao JC, Gueiros LA, Porter SR. Oral manifestations of syphilis. Clinics. 2006; 61:161-6.

2. CDC. Transmission of primary and secondary syphilis by oral sexChicago, Illinois, 1998-2002. MMWR. 2004; 53:966-8.

3. Bruce AJ, Rogers III RS. Oral manifestations of sexually transmitted diseases. Clin Dermatol. 2004; 22:520-7.

4. Fiumara NJ, Grande DJ, Giunta JL. Papular secondary syphilis of the tongue. Oral Surg Oral Med Oral Pathol. 1978; 45:540-2.

5. Mani NJ. Secondary syphilis initially diagnosed from oral lesions. Oral Surg Oral Med Oral Pathol. 1984; 58:47-50.

6. Shimizu T, Shinogi J, Majima Y, Sakakura Y. Secondary syphilis of the tonsil. Arch Otorhinolaryngol. 1989; 246:117-20.

7. Aquilina C, Viraben R, Denis P. Secondary syphilis simulating oral hairy leukoplakia. I Am Acad Dermatol. 2003; 49:749-51.

8. Sellati TJ, Wilkinson DA, Sheffield JS, Koup RA, Radolf JD, Norgard MV. Virulent Treponema pallidum, lipoprotein, and synthetic lipopeptides induce CCR5 on human monocytes and enhance their susceptibility to infection by human immunodeficiency virus type 1. Infect Dis. 2000; 181:283-93.

9. Tang MBY, Yosipovitch G, Tan SH. Secondary syphilis presenting as a lichen planus-like rash. JEADV. 2004; 18:185-7.

10. Dickenson AJ, Currie WJ, Avery BS. Screening for syphilis in patients with carcinoma of the tounge. Br J Oral Maxillofac Surg. 1995; 33:319-20.

Received: 18/06/2012 • Accepted: 30/07/2012 


\title{
Mukozni plak na jeziku kao jedina manifestacija sekundarnog sifilisa - prikaz bolesnika
}

\author{
Milan Bjekić', Sandra Šipetić \\ ${ }^{1}$ Gradski zavod za kožne i venerične bolesti, Beograd, Srbija; \\ ${ }^{2}$ Institut za epidemiologiju, Medicinski fakultet, Univerzitet u Beogradu, Beograd, Srbija
}

\begin{abstract}
KRATAK SADRŽAJ
Uvod Sifilis je polno prenosiva infekcija koju izaziva anaerobna spiroheta Treponema pallidum. Promene na sluzokoži usne duplje javljaju se u svim stadijumima bolesti, a lezije tokom ranog sifilisa su veoma kontagiozne, kao i krv i pljuvačka inficiranih osoba. Cilj rada je bio da se na slučaju iz svakodnevne prakse ukaže na značaj lezija sekundarnog sifilisa u usnoj duplji u diferencijalnoj dijagnozi oralnih oboljenja.

Prikaz bolesnika Muškarac star 38 godina bez subjektivnih smetnji javio se lekaru zbog sumnje da je inficiran sifilisom. Pregledom je utvrđen mukozni plak na jeziku, dok na koži i sluzokožama nije bilo nikakvih promena. Limfne žlezde nisu bile uvećane, a serološki testovi na sifilis bili su pozitivni. Nakon terapije benzatin-penicilinom $G$ promene na jeziku su se povukle.

Zaključak O sifilisu treba razmišljati u diferencijalnoj dijagnozi oboljenja usne duplje.
\end{abstract}

Ključne reči: sifilis; oralne lezije; mukozni plak

\section{UVOD}

Sifilis je bakterijska polno prenosiva infekcija koju izaziva spiroheta Treponema pallidum. Ako se ne leči, prolazi kroz sledeće stadijume: primarni, sekundarni, latentni i tercijarni. Osim $\mathrm{u}$ latentnom stadijumu, $\mathrm{u}$ svim ostalim opisane su promene $\mathrm{u}$ usnoj duplji [1]. Tokom sekundarnog stadijuma oralne lezije, pljuvačka i krv su veoma kontagiozni.

Nezaštićeni oralni seksualni odnosi su veoma čest način prenošenja ovog oboljenja, naročito u populaciji muškaraca koji upražnjavaju seks s muškarcima [2]. Cilj rada je bio da se na slučaju iz kliničke prakse ukaže na značaj lezija sekundarnog sifilisa u usnoj duplji, kao i na neophodnost razmišljanja o ovom „velikom imitatoru“ $\mathrm{u}$ diferencijalnoj dijagnozi oralnih oboljenja.

\section{PRIKAZ BOLESNIKA}

Muškarac star 38 godina, biseksualne orijentacije, javio se u avgustu 2010. godine Gradskom zavodu za kožne i venerične bolesti u Beogradu zbog sumnje da je oboleo od sifilisa. Podaci iz anamneze su otkrili da je tri meseca ranije nekoliko puta imao seksualne odnose s bračnim parom koji se leči od ove polne infekcije. Upražnjavao je nezaštićene oralne odnose i receptivni analni seksualni odnos.

Bolesnik nije imao subjektivnih smetnji. Negirao je postojanje ranica u anogenitalnoj regiji i usnoj duplji. Pregledom nisu utvrđene nikakve promene na koži, niti u anogenitalnoj regiji, a limfne žlezde nisu bile uvećane. Pregledom usne duplje na jeziku je primećen asimptomatski, jasno ograničen i blago eleviran mukozni plak prečnika oko $1 \mathrm{~cm}$ (Slika 1). Serološki testovi na sifilis VDRL (Venereal Disease Research Laboratory) i TPHA (Treponema Pallidum Haemagglutination Assay) bili su reaktivni, a VDRL test u titru bio je 1:32.

Bolesnik je lečen jednokratnom dozom od 2,4 miliona i.j. benzatin-penicilina G. Dve nedelje nakon terapije promena na jeziku se potpuno povukla, a posle tri meseca kontrolni VDRL test je postao nereaktivan.

\section{DISKUSIJA}

Sifilis je „veliki imitator“, a promene na sluzokoži usne duplje mogu biti prvi znaci manifestacije bolesti. Nakon orogenitalnog ili oroanalnog seksualnog odnosa na mestu ulaska T. pallidum u usnu duplju obično se posle tri nedelje (inkubacija od 10 do 90 dana) javlja primarni šankr - ulcus durum, jasno ograničena solitarna bezbolna ulceracija s čistom, očvrslom bazom i tvrdim uzdignutim ivicama, lokalizovana obično na usnama ili jeziku, praćena cervikalnom limfadenopatijom. Opisana je retka pojava šankra na tonzilama i na farinksu [3].

Kod ovog bolesnika nije utvrđen primarni stadijum infekcije, a anamnestički podaci ukazuju na to da se primarna promena mogla nalaziti u usnoj duplji ili u rektumu. Na navedenim lokacijama šankr se često previdi, bolest se ne dijagnostikuje i ne leči, te se nakon 4-10 nedelja bakterija diseminuje hematogenim putem i nastaje sekundarni stadijum sifilisa.

U sekundarnom stadijumu bolesti kod najmanje $30 \%$ obolelih javljaju se i oralne lezije u vidu makulopapuloznih sifilida, mukoznih plakova i retko nodularnih manifestacija [1]. Makulozni sifilidi se najčešće javljaju na tvrdom nepcu u vidu crvenih kružnih, ravnih do blago uzdignutih makula. Papulozni sifilidi na bukalnoj sluznici su predstavljeni eritematoznim čvrstim papulama sa sivkastim centrom koji može da ulceriše. Poseban oblik papuloznih sifilida čine veoma infektivni condylomata lata, svetle ružičasto-sivkaste papule prečnika $0,5-2 \mathrm{~cm}$, zaravnjene i vlažne erodirane površine, prekrivene beličastim sekretom, smeštenim na uglovima usana. Nodularni sifilidi se mogu javiti u predelu vermiliona u vidu čvorića koji klinički podsećaju na keratoakantom.

Mukozni plakovi su ovalni ili kružni plakovi s istanjenom sluzokožom na kojoj mogu nastati plitke erozije prečnika oko 1 $\mathrm{cm}$, prekrivene sivim mukoidnim eksudatom s eritematoznom ivicom na bukalnoj sluznici i jeziku, ali ponekad i na farinksu, gingivi i tonzilama. Nekada se ove promene spajaju, te čine serpiginozne lezije, tzv. snail track ulceracije.

Kod našeg bolesnika mukozni plak na jeziku je bio jedina manifestacija sekundarnog sifilisa. U literaturi je opisano samo nekoliko slučajeva gde su izolovane oralne lezije bile jedine 
manifestacije ovog stadijuma bolesti [4-7]. S obzirom na to da su ove promene veoma infektivne, važno ih je blagovremeno dijagnostikovati i započeti s odgovarajućom terapijom. Jednokratna doza benzatin-penicilina G od 2,4 miliona i.j. jeste terapija izbora za sekundarni sifilis.

Promene koje se ispoljavaju u tercijarnom stadijumu sifilisa u usnoj duplji su sifilitične gume i sifilitična leukoplakija [1]. Gume, destruktivni granulomi, obično se javljaju na tvrdom nepcu i jeziku u vidu jednog ili više bezbolnih čvorova koji mogu ulcerisati, izazvati oštećenje koštanih struktura, perforaciju nepca i pojavu oronazalnih fistula. Sifilitična leukoplakija se javlja u vidu homogenog beličastog polja koje zahvata veću površinu dorzalne strane jezika. Ovaj glositis može maligno da alteriše.

Polimorfizam kliničkih promena u usnoj duplji kod sifilisa, njihova visoka infektivnost i činjenica da sifilis značajno olakšava prenos HIV infekcije ukazuju na to da ovo oboljenje ne treba prevideti u diferencijalnoj dijagnozi bolesti oralne mukoze, kao što su kandidijaza, oralna čupasta (engl. oral hairy) leukoplakija, lihen planus i oralni skvamocelularni karcinom [7-10].

Rano otkrivanje često tipičnih oralnih lezija olakšava postavljanje dijagnoze i omogućava blagovremeno lečenje bolesnika sa sifilisom. Zbog toga je veoma važno pažljivo pregledati usnu duplju svih osoba za koje se sumnja da su oboleli od ove bolesti i stalno ih edukovati o značaju redovne upotrebe sredstava za zaštitu i tokom oralnih seksualnih odnosa.

\section{NAPOMENA}

Ovaj rad je nastao u okviru projekta br. 175042 (2011-2014. godine), koji u celini finansira Ministarstvo prosvete i nauke Republike Srbije. 